\title{
PEACEFUL MEANS FOR SETTLEMENT OF INTER-STATE DISPUTES: REFLECTIONS, ADVANTAGES AND DISADVANTAGES
}

\author{
Elena Temelkovska-Anevska \\ Assistant Professor PhD, Faculty of Law, University "St. Clement of Ohrid"- Bitola, MACEDONIA \\ e.temelkovska@gmail.com
}

\begin{abstract}
Disputes, tensions and conflicts are present in all spheres of human society, either at the national, regional, or international level. Therefore, international law requires peaceful methods for dispute settlement and somehow it becomes an imperative in international relations.

From a legal point of view, the dispute settlement in international law creates an obligation for states to settle their disputes in accordance with the international law by using the peaceful means and mechanisms. They can choose between diplomatic, judicial and institutional means. Such means include legally binding and non-binding mechanisms: negotiation, good offices and conciliation (as diplomatic means and non-binding third party facilitation); intervention of an international or regional organization and its bodies or representatives (as an institutional mechanism), and legally-binding mechanisms such as arbitration and international adjudication (as judicial means). Although there is a specific obligation for the states to settle their disputes through peaceful means, they are also free to choose the most suitable peaceful mechanism for their dispute.

The distinction between the diplomatic and judicial means is related to the difference between two categories of disputes: legal and political. The legal disputes are more related to judicial means of settlement, within the international law. Political disputes use diplomatic channels and political principles instead of international law in order to settle disputes. The diplomatic means are characterized by the lack of binding effect to any conclusion and taking into account all relevant circumstances. By their nature they are less ambiguous compared to judicial means. Arbitration as judicial mean is optional, more flexible and adapted to the objectives of the states. Its conclusions have binding effect. The International Court of Justice and its proceedings are also binding, more rigid, less flexible and take only legal aspects as relevant.

States are not always willing to make conciliation in terms of dispute settlement, mostly due to national interests and sovereignty. When states need to choose among these various means, they have to take into consideration their mutual relations and the nature of their dispute.

Nowadays, inter-states disputes are real problems in maintaining stability and promoting peaceful relations between states. Consequently, the aim of this paper is to identify the peaceful means and delicate techniques known in the international law and to distinguish their advantages and disadvantages and how states can apply them in order to reach an acceptable and reasonable solution and reduce the risk of new disputes and conflicts between them in future.
\end{abstract}

Keywords: dispute, dispute settlement, peaceful means, United Nations. 


\section{INTRODUCTION}

Tensions and conflicts in the contemporary world can happen anywhere, anytime and between any states. Maintaining stability and promoting peaceful relations and conditions between states and within states initiate the need to create a new approach on the dispute settlement. Addressing conflicts and mitigating the threat of new disputes and conflicts in foreseeable future is in the interests of both states and their people.

The term 'dispute' is defined as "a disagreement on a point of law or fact, a conflict of legal views or of interests between two persons". This definition was given by the Permanent Court of Justice in the Mavrommatis Palestine Concessions case in $1924 .^{1}$

Dispute settlement requires a number of delicate techniques. While negotiation is a most common method for states to use for the settlement of their disputes, other means and methods, such as the role played by international or regional organizations can also be used as an alternative in the framework of the so-called institutional methods for resolution of disputes.

Since the establishment of the United Nations (UN) in 1945, the categories of 'peace and security' have become the central topics in international society. Charter of the UN in Article 1 states that UN as universal international organization has a primary purpose to "maintain international peace and security, using peaceful means in conformity with the principles of justice and international law, adjustment or settlement of international disputes or situations which may lead to breach of the peace". Article 2 (3) requires that "all member states are to settle their international disputes by peaceful means in such a manner that international peace and security, and justice are not endangered". Article 33 (1) in Chapter VI of the UN Charter provides that:

The parties to any dispute, the continuance of which is likely to endanger the maintenance of international peace and security, shall, first of all, seek a solution by negotiation, inquiry, mediation, conciliation, arbitration, judicial settlement, resort to regional agencies or arrangements, or other peaceful means of their choice.

Which technique for peaceful settlement of disputes will be used is a question of choice, but that choice should be in accordance with the nature of the dispute itself - is it a legal or a political one. Although almost every dispute can be settled either by diplomatic or by judicial means, in general, legal disputes are settled by judicial means and political disputes by diplomatic means. It is not an easy task to make a distinction between these two categories. The theory distinguishes them by one key element - the source of the dispute. Political disputes are those where at least one of the parties wishes modification of the lex lata, while in legal disputes parties disagree over the application and interpretation of existing legal rules ${ }^{2}$ (Lapidoth, p.7).

International law obligates the states to settle their disputes and misunderstandings by peaceful means. However, there is no obligation to use a specific mechanism, because they may choose between diplomatic or judicial means.

The need for peaceful settlement of disputes has developed in the last century. One of the reasons was the universal prohibition of use of force which intention was to eliminate war as an instrument for dispute resolution. Additionally, Article 2 (3) of the Charter of the UN created a parallel obligation for non-violent dispute settlement. Moreover, the interdependence of states has formed the need for coordination and cooperation between states in different matters which can easily lead to disagreements and conflicting interests in a level that is unavoidable.

The key distinction is made between diplomatic and judicial settlement of disputes. The difference concerns two issues: in the case of judicial dispute settlement by an arbitral award or a court, only legal aspects are relevant and the final resolution has binding nature for both parties of the dispute. Contrary, in the case of diplomatic procedures all considerations are relevant and the final resolution is not binding on the parties.

The Security Council and the General Assembly as organs of the UN have competence for dispute settlement in accordance with the diplomatic means, and the resolution that may be adopted has the nature of recommendation. The only exception is the situation when the Security Council acts under Chapter VII (in cases of a breach of the peace, threat of peace or act of aggression) of the UN Charter and adopts decisions

\footnotetext{
${ }^{1}$ Permanent Court of Justice in the Mavrommatis Palestine Concessions (Jurisdiction) case. PCIJ, Series A, No.2, at.11.

${ }^{2}$ For instance, if the dispute occurs and it is about a boundary that has been established by the parties, in that case a legal dispute may involve disagreement about the exact emplacement of the border, while a political dispute would occur if one of the parties or both of them requested that boundary to be changed for any reason (such as, demographical, geographical or strategic reason).
} 
that are binding for the parties.

In practice, there are cases where the title of the forum for dispute settlement does not conform to its real nature - there are examples of conciliation commissions that adopt resolutions binding by their nature, and for that reason their name does not correspond with its real nature, because they are in fact arbitral tribunals instead of conciliation commissions. Contrary, there are examples of Arbitration Commissions that have only advisory functions.

International law recognizes different peaceful means for different kinds of disputes. Some of them offer a possibility for replacement - if a certain mechanism was not successful, the parties should have an option to choose another one. For instance, in many cases, if conciliation has failed, the dispute should be submitted to arbitration; or if the dispute cannot be resolved by negotiations it shall be settled by good offices, mediation, conciliation or arbitration. Moreover, there are a number of agreements on the peaceful settlement of international disputes in which the recourse to arbitration or conciliation is optional.

All mechanisms, except for negotiations, require the consent of both parties. If the dispute cannot be settled by some of these mechanisms, upon one party's request, there is an obligation to submit the dispute to a Fact-finding Commission. The report of this commission is not binding, but it have to be considered 'in good faith' by both parties. The parties of the dispute may previously agree to submit dispute to the International Court of Justice or arbitration.

The diplomatic techniques have specific nature, because they can be divided on measures to prevent disputes and measures intended to solve them (Muruthi, 2015). In international law, the paradigm of a dispute or conflict over state national interests often introduces the distinction between 'dispute prevention' and 'dispute settlement'. Their distinction is not fixed and depends on the perception of the parties. Many disputes were intentionally left 'legally unsettled' for several years with an expectation of negotiating an agreed solution (Petersman, 2004, p.37)

When a dispute occurs there are two preliminary issues. The first one is about the subject matter of the dispute, while the second is about the possibility of the dispute to endanger the maintenance of the international peace and security. The first issue is related to the characteristics of the subject matter of the dispute and available means (legal and political) for its settlement. The second issue covers the multilateral disputes, because the bilateral disputes are rarely included in this category (Palmer, 2012, pp.40-44).

International law recognizes an extensive list of methods for dispute settlement, which are divided in two main categories - diplomatic and judicial methods, and each of them has its own practice and features (Merrills, 2011). These methods are precisely elaborated in this paper.

The literature of dispute settlement recognizes three approaches to disputes: a power-based, a rights-based, and an interest-based approach. In the first approach, the parties attempt to define which one of them is most powerful. In international relations, the most extreme version of this approach is the war. The aim of the second approach is to define which of the parties is right using some standards described in the international law. In the third approach, the parties make an effort to resolve their disputes by discovering their interests and solutions which will connect their differences, aspirations and needs in a satisfactory manner acceptable to both of them. The three approaches are related and parties may easily shift from one to another approach (Ury and al., 1988, p.9). The United Nations structure incorporates all three approaches, but different UN organs focus on different approach for settlement of disputes. For instance, the interest-based approached is most used in the cases of 'good offices' and 'mediation' by the Secretary-General of the UN and his special representatives. The International Court of Justice uses the right-based approach and the Security Council uses broad variety of power-based procedures at its disposal (Peck, 1996, p.10-13).

\section{DIPLOMATIC MEANS}

\subsection{Direct Negotiations}

Direct negotiations are the most used and ubiquitous mechanism for dispute settlement. They should be the first step in the resolution of any dispute. They can be obligatory or optional. The parties usually will try to solve their dispute by direct negotiations and if the negotiations failed, they will resort to another mechanism for dispute settlement. Negotiations and the duty to negotiate have their origin in customary international law, conventional law and are also recognized in the general customary law. One of the characteristics of the negotiations is that they can occur at different levels: between administrative agencies and experts, ministries of foreign affairs, diplomats or even at a summit or a conference. However, the most common level is between ministries of foreign affairs.

The successfulness of direct negotiations depends on the determination, a good will and readiness of the 
participants to reach a compromise or an agreement. Furthermore, maintaining secrecy and keeping the negotiations away from the public and the media is important element in order to make a compromise and overcome obstacles. Publicity and the media coverage of the negotiations may make them impossible, because the pressure and demands coming from the public, and especially the public opinion, sometimes can be very difficult to avoid (Lapidoth, pp.12-13).

The exhaustion of negotiations is a precondition for the resort to another means of dispute settlement. In many cases, it is complicated to detect if and when the negotiations have been exhausted. There are also cases where a party refuses to negotiate, regardless of its obligation to do so. Such a refusal may be a consequence of a very bad mutual relations ${ }^{3}$ or a lack of recognition ${ }^{4}$.

Before the beginning of the negotiations, there are a number of conditions required for the negotiations. First requirement is the existence of recognizable parties - two or more. Next requirements involves a subject of mutual interests for the parties, a dispute that is negotiable, motivation to negotiate, a desire and need among the parties to reach an agreement, a strong will to find a quick solution for their dispute strengthened with the time deadline, and an applicable and appropriate agreement.

The process of negotiation can be divided in four phases: pre-negotiation, conceptualization, bargaining and settlement. The first phase covers the issues of identification of the parties, detection of mutual interests and selection of a forum for communication. The next phase identifies the positions of each of the parties and the subject matter of the dispute. The third phase is the so-called 'bargaining phase'. In this phase, the parties discuss their positions and negotiate the terms and conditions which will lead to a solution. The final phase is the phase of reaching an agreement.

Among the benefits and advantages of negotiations are the lower costs, the rapidity of the dispute resolution, the direct communication between the representatives of the parties, flexibility and confidentiality of the process. The negotiations can be more productive in comparison with other peaceful means for dispute settlement because the parties are familiar with the subject matter of their dispute and any additional disagreements between them can be easily recognized and solved (Strutt, 2014, pp.1-3).

It is absurd that the strongest benefits can induce the greatest disadvantages and weaknesses of direct negotiations. For instance, although speed and flexibility are considered as advantages they can easily undermine the negotiations. The flexibility can be abused by one party to harm the other. This is the case when in the absence of regulation, the natural power of one of the parties prevails and this party can influence the settlement of the dispute. Speed, on the other hand, can lead to unbalanced settlement and resentment on the side of one of the parties.

The negotiations do not necessarily end with an agreement, although that is their aim. Among the disadvantages of negotiations is the possibility to last endlessly, in order to cover the failure of resolving the dispute: not resolving it is "better" than admitting the failure of negotiations. However, if there is a will on the side of the parties, they can be conducted fast and flexible. Moreover, during the negotiations the parties must manifest their 'good faith' for reaching a settlement. The term 'good faith' is also flexible and it may have different meanings in different circumstances depending on the dispute. In addition to the different features of negotiations it is worth mentioning the distinction between bilateral and multilateral negotiations, in particular, on the issue of the dynamics, which can play a major role in the case of multilateral negotiations (Palmer, 2012, pp.41-42).

An example for successful negotiations is the case connected to NATO air attacks (Operation Allied Force) against Federal Republic of Yugoslavia (FRY or Serbia today). The Embassy of People's Republic of China in Belgrade, the capital city of FRY, was an accidental target of an air strike on $7^{\text {th }}$ of May 1999. The USA officially stated that the bombing was accidental and a "tragic mistake". According to the US government, the main intention had been to bomb the nearby Directorate for Supply and Procurement of FRY and that Central Intelligence Agency $(\mathrm{CIA})^{5}$ had identified the wrong coordinates for Yugoslav military target on the same street. According to the statement from the Chinese government, the bombing was a 'barbarian act'. The negotiations between USA and China led to Memorandum of understanding, signed on $30^{\text {th }}$ of July 1999. The USA agreed to pay a compensation of 4.5 million US dollars to China for the families of the tragically deceased and injured people in the bombing. The USA and China signed two compensation agreements on $16^{\text {th }}$ of December 1999 about the material damage caused to the diplomatic property on both sides. In the first agreement, the USA agreed to pay a compensation of 28 million US dollars for the damage

\footnotetext{
${ }^{3}$ The relations between Iran and the USA in 1979-1980, at the time of hostage crisis.

${ }^{4}$ Clear example is the non-recognition of Israel by the Arab States in the past.

${ }^{5} \mathrm{CIA}$ director George Tenet testified before a Congressional Committee that this air attack was the only one in the operation that was organized and directed by the CIA.
} 
caused to the Chinese Embassy in Belgrade. With the second agreement, China agreed to pay 2.87 million US dollars as a compensation for the damage caused to the US diplomatic and consular properties in China, caused by the Chinese protesters (Murphy, pp.99-102). ${ }^{6}$

The negotiations end when the parties of the dispute reach a compromise or an agreement, although negotiations do not imply an obligation for the parties to reach an agreement. In a situation where the negotiations are not successful and the dispute threatens the international peace and security, the article 33 of the UN Charter recommends that parties need to continue with other methods for peaceful settlement of disputes, usually the so-called good offices.

\subsection{Good Offices}

'Good offices' as a mechanism for dispute solution differ from the negotiations because it involves an intervention of a third entity/party who is not a party to the dispute. The third party can be involved on the initiative of both parties of the dispute. When direct negotiations reach the point where no progress is possible, especially because of fundamental disagreement between the opposing parties, the 'good offices' can be applied. As a term it has two meanings, which are different, but closely related. The first meaning, describes the third party as a subject who will encourage the parties to resume the direct negotiations. The second meaning of the term 'good offices' include both mediation and 'good offices'. It is connected with any non-structured form of support given by a third party. However, there is a difference between mediation and 'good offices'. The third party in the 'good offices' has a passive role and tends to bring the parties to negotiations again. This means that the third entity communicates with both of the parties separately and does not participate in the resolution of the dispute, because the final decision about this issue is on the parties. On the other hand, the mediator has an active role in the process, offering suggestions and proposals for resolution of the dispute.

One of the main characteristics of this mechanism is the necessary mutual consent of both parties. If the parties of the dispute cannot reach agreement by direct negotiation, they may jointly seek the good offices by a third party, but it does not mean that there is an obligation for the parties to submit their dispute to this method (Lapidoth, p.14). The third party can be represented by a state, international organization (United Nations), or a prominent person, such as the UN Secretary-General. The third party must be a neutral, impartial and trustworthy, with an ability to resume the favorable atmosphere between the parties.

An example of successful 'good offices' is the peace agreement between Russia and Japan, signed on $5^{\text {th }}$ of September 1905. The US President Theodore Roosevelt had a role of a third party in the 'good offices' in this case. The Nobel Peace Prize in 1906 was awarded to Roosevelt for having negotiated peace in the Russo-Japanese war in 1904-1905 and for his contribution for resolving the dispute with Mexico by resorting to the Permanent Court of Arbitration in 1902 for the case USA vs. Mexico (Pious Fund of the Californias case).

The dispute about the name issue between Greece and Macedonia is another example for 'good offices'. It began with the application of the Republic of Macedonia for UN membership. After examining the application of the Republic of Macedonia, the UN Security Council adopted the Resolution 817 on $7^{\text {th }}$ of April 1993. The Security Council noted the differences over the name of the state (Republic of Macedonia) and recommended to the UN General Assembly the admission by the provisional reference "the former Yugoslav Republic of Macedonia" until the settlement of the name dispute with Greece. The Security Council welcomed the Co-Chairmen of the Steering Committee of the International Conference on the Former Yugoslavia (Cyrus Vance and Lord David Owen) to settle the dispute. In the meantime, the 'good offices' turned into mediation. The UN Secretary-General appointed a special representative Cyrus Vance as a mediator, who was replaced with Matthew Nimetz in December 1999.

The 'good offices' can be finished in two possible ways: when the parties resume the direct negotiations or when the third party does not succeed to create a positive ambience and communication between the opposing parties and the negotiations cannot be resumed.

\subsection{Mediation}

Mediation is the second most used peaceful means for dispute settlement after the direct negotiations. It involves a third party-mediator who attempts to settle a dispute. It is defined as a non-binding, but flexible,

\footnotetext{
${ }^{6}$ Large demonstrations escalated in China directed to consular offices of the USA and other NATO countries located in China, as a reaction to the bombing, but there were no injuries on the side of the USA embassies staff. The residence of the US Consul in Chengdu was damaged by fire and protestors tried to damage the consulate in Guangzhou, but there were no injured on the side of the staff of US embassies and consulates during demonstrations.
} 
voluntary and confidential process in which the third neutral party actively assists in settlement of the dispute

The key figure in mediation is the mediator. A mediator is an active participant in the process of dispute settlement between the opposing parties and he offers an assistance, guidance and help to both parties, in order to understand all important points of their dispute. Mediation can be performed by representatives of a state or an NGO, by an international organization or its functionaries, such as Secretary-General of the UN and its representative, or by respected and distinguished person. Although designation of a distinguished personality is more common, the representative of a powerful state or international organization has more chances for success due to the ability of the powerful state to influence the parties and their behavior. A person can be designated for mediator only by consent of the parties. Mediation can be also initiated by one of the parties or even by the mediator himself/herself (Bernier and Latulippe, p.4). In practice, it is difficult to find such a person or a state who would willingly agree to mediate, since this mechanism is a difficult assignment which requires patience and proficiency. According to that, not all mediations achieve to end the dispute.

The duty of a mediator is to clarify the position of each party, to improve the ambiance and to make proposals for a solution of the dispute. As a figure, he/she is characterized with objectivity, neutrality, discretion, impartiality and independence. His/her major duty is to discreetly transmit the proposals of one party to the other, on separate meetings. For that reason, the mediator has a very important role in making the process much easier for the parties, especially in a situation when the relations between the parties reach an impasse: in such a case the mediator will continue to work with each party separately, until reaching a compromise. The mediator is interested to bring the dispute to an end, because it demonstrates his/her success (Lapidoth, p.15).

The role of the mediator is to create a positive atmosphere in which the parties can communicate, to assist in breaking impasses, to prevent direct confrontation between the parties. For these reasons, the mediation is often explained as 'assisted negotiation'.

The process of mediation can be also explained as a communication assisted by a third party. There are many ways to accomplish the communication between the parties: they can communicate directly between each other; the mediator can assist their communication; or the mediator can communicate with one of the parties separately.

The contemporary form of mediation is more formal compared to negotiation. The formality is corroborated with the acceptance by institutional bodies who are concerned with the vigorous process and the rules and regulations of mediation.

Among the most common advantages of mediation is the flexibility, the necessity of consent, the inexpensive procedure, the opportunity of the parties to have control over the process and the resolution of their dispute.

The flexibility is usually restricted by the will and readiness of the parties to cooperate with the support from the mediator. It can be also reflected in the speed of solving the disputes.

The consent of the parties is necessary at all points of the mediation in order to lead to successful dispute resolution. In many cases, the consent can be the basis for agreement between the parties.

The cost is under direct control of the parties. Their wish for quick settlement of the dispute and the level of cooperation with the mediator, can lead to small costs for the parties (Keith, p.4).

Although the low cost was mentioned in the advantages of the mediation it is also a part of the disadvantages. Normally, mediation is not cheap: it is much more cost effective compared to other peaceful means, but only if it succeeds in the dispute settlement. If it fails, the final resolution of the dispute will be delayed and it will lead to high expenditure for no result.

Other disadvantage is the consensual nature of mediation, which can cause failure of the mediation even with the assistance of the mediator. The vulnerability of the process may be increased by the parties with the misuse of mediation and their aspiration to delay the settlement of the dispute.

The non-binding character of the opinions and suggestions of mediator is a disadvantage, too. However, when parties achieve the settlement, the agreement between them needs to be enforced (Keith, p.4).

One of the characteristics of mediation is the consent of all parties, because if there is no prior commitment, they have to agree to the mediation, additionally. The services offered by the mediator are not obligatory for the parties - they can either accept or reject them, but they will usually agree to mediation if they are looking for a compromise (Keith, p.5).

The successful end of mediation depends on timing. For instance, in many cases the mediator entered the 
scene in a period when the parties are already exhausted of the war or after many unsuccessful attempts to solve their dispute.

In order to solve the dispute successfully, mediation also needs confidentiality.

The parties of the dispute are often facing difficulties to find a person or a state who would agree to take the role of a mediator since mediation is a very complex mission which requires a lot of time and tolerance and at the end cannot guarantee the success. Cautious selection of the mediator can also facilitate the differences between the parties, particularly the cultural one. The aim of the mediation is to assist the communication between the opposing parties and to help them to avoid any future misunderstanding.

As one of the most used peaceful means for dispute settlement, mediation is flexible and it is not restrained by legal structures. However, it is still difficult to find acceptable mediator for a dispute. Mediation as a technique is considered to have active involvement of a third party, which will make an attempt to help the parties to settle their dispute and reach an agreement. Mediators may use different ways to persuade the parties: they can encourage them to find a rational reason to make approach to the other party of the dispute; they help them to see the weaknesses and strengths of their approaches or positions; and to introduce a sense of fairness and honesty between them (Palmer, 2012, p. 42).

Compared to arbitrators, the role of mediators is much more active and intrusive. Mediator identifies the fundamental interests and positions of the parties on joint, but also separate and confidential meetings. This kind of proactive involvement of the mediator can contribute to the success of mediation (Bernier and Latulippe, p.4). Different mediators have different styles and different skills. Their role is not a role of a judge, but they need to be critical in the process of facilitating and guiding the parties to reach a settlement (Brennan, 2015, pp.145-146).

An example for effective mediation is the conflict between Chile and Argentina about the Beagle Channel. The Beagle conflict was a border dispute over the possession of Lennox. Piston and Nueva islands and the scope of maritime jurisdiction related with those islands that brought Chile and Argentina to the edge of war in 1978. The conflict began in 1904 with the first official Argentine claims over the islands that had always been under Chilean control. The Pope John Paul II was the mediator in this case which was resolved in 1984 when Argentina recognized the islands as Chilean territory. The Pope had two proposals: the first one from 1980 was accepted by Chile and rejected by Argentina, and the second one from 1984 was a subject of referendum in Argentina, which produced a result of $82.6 \%$ in favor of the papal proposal. The both parties accepted the mediation of Vatican in 1979 with the Act of Montevideo and after 5 years, in 1984, they signed the Treaty of Peace and Friendship at Vatican City giving the islands to Chile and maritime jurisdiction to Argentina.

The practice recognizes other examples of successful mediation: the mediation of the Soviet Union in the dispute between India and Pakistan in 1966 and the mediation of Algeria in the dispute between USA and Iran regarding the hostage crisis in 1980-1981. In this case, Algeria as a mediator suggested the Ayatollah Ruhollah Khomeini to make "a gesture of goodwill" towards Algeria as a third party, and not towards the USA.

The mediation ends when the dispute is solved in accordance with the proposals of the mediator and the parties reach an agreement or when all suggested proposals are not accepted by the parties and the dispute is not solved.

\subsection{Inquiry (Commission of Inquiry)}

Inquiry is similar to 'good offices' and can be used in two related, but different connotations. The first connotation includes disputes between states created by disagreements over facts and a third party with a task to solve those disputes. The second meaning of the term 'inquiry' is related to a specific institutional arrangement or settlement which needs to clarify only a specific point of fact ${ }^{7}$.

The main purpose of the inquiry is to facilitate the solution of the dispute that occur from the difference of opinion on facts by clarifying these facts, For that reason, the inquiry is also known by the term 'fact-finding' and commission of inquiry as 'fact-finding commission' (Peters, 2003, p.5).

\footnotetext{
'In the practice of the international law, the term 'enquiry' is used as an equivalent of the term 'inquiry'. Geoffrey Palmer proposed to distinguish these two similar terms. He recalled the distinction made in the New Zealand Oxford Dictionary from 2005. According to the explanation given in it, there is a useful distinction between these terms, although they are used alternatively. The term enquire means 'to ask something', in general context, while inquire means 'to make a formal investigation'. Although the international practice is variable, the same distinction refers to terms 'inquiry' and 'enquiry'.
} 
This mechanism was established as a 'Commission of inquiry' in 1899 and 1907 by the Hague Conventions for the Pacific Settlement of International Disputes. The later convention has introduced the functioning and the procedure for the establishment of the commission of inquiry. This technique is based on the hypothesis that if an authoritative and respected third party solves the disagreement, than the dispute solution is obvious. One of the characteristics of the inquiry is the role of the commission in clarifying the facts or the factual question of the case. The commission does not explain or resolve the question of legality.

The procedure established by the 1907 Hague Convention proved to be successful, but it has been used in a very small number of cases. It was replaced with other ad hoc fact-finding techniques ${ }^{8}$ used by international organizations, such as the United Nations, previously the League of Nations, some of the specialized agencies of the United Nations (the International Labour Organization), etc.

This mechanism was rarely used in practice. In fact, the inquiry was used in few cases only: Dogger Bank in 1904, Tavignano case in 1912, Tiger case in 1918, Tubantia case in 1922 and Red Crusader in 1961.

The necessity for impartial investigation of the facts of the dispute was obvious in the period of events that led to Spanish-American war in 1898. Hostilities began in February 1898 in the aftermath of the internal explosion of the USS Maine (ACR-1) - the American naval battleship - that sank in Cuba's Havana harbor during the Cuban revolt against Spain. The ship was destroyed by a massive explosion that led to deaths of 250 out of 355 American crew members aboard. Apparently on a friendly visit, the Maine had been sent to Cuba to protect the interests of American citizens after a rebellion against Spanish in Havana in January 1898. Most American leaders, including the US president William McKinley, declared that the cause of the explosion was unknown, but the American public opinion blamed Spain for the explosion. In order to solve the case, they formed two commissions for investigation. The US investigation by an official US Navy Court of inquiry concluded that the ship was destroyed by an external explosion caused by a mine that was set off under the ship's hull. The Spain's investigation came to opposite conclusion: the explosion was linked with factors within the ship. These different reports about the cause of the explosion made the war inevitable. Almost 80 years later (in 1976), a team of American naval investigators concluded that the explosion was not caused by Spanish mine or sabotage, but by a fire that ignited its ammunition stocks. However, there were different conclusions about how the forward magazines could have exploded.

The function of the Commission of inquiry is to investigate the facts of the dispute and set them out in a report. The Commission may be appointed by consent (agreement) between the parties of the dispute. The most famous case including inquiry is "Dogger Bank case" between United Kingdom and Russia'. The case was about the attacks by Russian warships on British fishing vessels in the North Sea in October 1904. The Russian warships were engaged in the war with Japan and attacked the British fishing trawlers because they thought they were Japanese torpedo boats (Palmer, 2012, p.42). The Dogger Bank incident almost led to war between Russia and Britain. The incident was dangerous due to Anglo-Japanese alliance. The Russian and the British governments signed a joint agreement in November 1904 in which they agreed to submit the case to an international commission of inquiry. In 1905 Russia voluntarily paid a compensation of 66.000 British pounds to the fishermen.

Another well-known case is the so-called Red Crusader case from 1961. It is about an incident that occurred in May 1961 between British fishing vessel and Danish gunboat. The commission of inquiry in its report concluded that Danish frigate "Niels Ebbesen" exceeded the legitimate use of armed force by firing without warning and creating a danger to human life on board the Aberden trawler Red Crusader. Although the inquiry does not aim to solve the dispute, but only to explain the facts of the dispute, the Red Crusader was the only case in which the commission of inquiry gives legal considerations and qualifications (about the legitimate use of armed force).

The inquiry is rarely used as an exclusive mechanism for dispute settlement, but it is more often used as a part or an addition to some of the other mechanisms.

The 'commission of inquiry' as a fact-finding commission can be a successful mechanism for dispute settlement only if the cause of disagreement is related to facts, and parties are motivated to accept the reality that their own version of the events may be incorrect.

The finding of the inquiry has non-binding nature, except in a situation where the parties has previously agreed the contrary.

\footnotetext{
${ }^{8}$ Fact-finding has been included in the 1982 United Nations Convention on the Law of the Sea, within the context of 'special arbitration' as one of the means that member states can choose.

${ }^{9}$ United Kingdom vs. Russia. 1905. Incident in the North Sea. 1 Hague Court Report 403.
} 


\subsection{Conciliation (Conciliation Commission)}

The conciliation as a mechanism has been established in the 1920s with the General Act for the pacific settlement of international disputes from 1928. Usually, it includes institutionalized and impartial commission which investigates the dispute and recommends possible solutions for settlement. Each of the parties specifies acceptance or rejection of the commission proposal. If the parties accept the proposal, the commission drafts an agreement, called procés verbal, which includes the conditions of the settlement. Although the commission's proposals are non-binding, there is an obligation for certain disputes to be submitted to conciliation.

The difference between this commission and the commission of inquiry is in the subject of investigation. The duties of the commission of conciliation are not limited only to clarifying the questions of fact. Moreover, conciliation can be very similar to mediation, because the conciliator can act as a mediator in convincing the parties to accept certain solution.

Among other features typical for conciliation is the possibility to use it in a combination with other diplomatic means, as an additional mechanism. The commission can be established as a permanent commission or on ad hoc basis and its proceedings are confidential. The decision which type of commission will be engaged depends on various factors, such as the attitude of the opposing parties, the contents of the instrument that created the commission, the perception of the conciliators about their function, etc. For that reason, in some cases, the procedure can be of a cooperative character and in others it can be more formal and can include pleadings by the opposing parties.

The procedure starts with the submission of the dispute to a commission upon the request of one party. The fact-finding commission is a combination of an inquiry commission and a conciliation commission. It consists of an odd number of members selected by each of the parties and a third member chosen by the two already appointed members. The important feature is the third person who may not have the nationality of either party and will take the position of a chairman. If the parties failure to agree on a chairman within three months starting from the request for the establishment of the commission, in that case the Secretary-General of the UN has a duty to appoint him/her. It is also possible one of the parties to refuse appointing its own member and this can be connected with a situation in which one of the parties wants to avoid previously committed arbitration. However, once the commission is formed, it will establish its procedure and the parties have to ensure that any information required by the commission is provided. The procedure ends with adoption of a report (by a majority vote) and its submission to the parties. The report includes the commission's findings and recommendations for reasonable and impartial solution of the dispute. These recommendations do not have to be in accordance with the legal situation and the parties do not have an obligation to adopt and implement the report, but to consider it "in good faith".

The references "findings" and "recommendations" are similar to other two peaceful means: conciliation and inquiry. Hence, the "findings" point in the direction of commission of inquiry and the "recommendations" can be connected to conciliation. The Vienna Convention on the Law of the Treaties and the Vienna Convention on Succession of States in Respect of Treaties provide conciliation as a technique for dispute settlement. The main aim of this technique is to assist a friendly settlement. The role of the Conciliation Commission is to examine the objections and claims, to hear the parties, and to make proposals for resolution of their dispute. The final and recommendatory award of the Conciliation Commission must be considered by the parties in a 'good faith' (Palmer, 2012, p.43). Conciliation is similar to arbitration concerning the neutral and impartial role of the Conciliation Commission, which is necessary in order to obtain the trust of the parties. In other aspects, conciliation is similar to mediation, too. In practice the conciliation is a precondition for submitting the case in front of arbitration. It is not intended to determine who is right or wrong and it plays an active role in examining the dispute. The proposal for the settlement is not necessarily based on law and is not binding for the parties (Bernier and Latulippe, p.6).

Conciliation appeared after the World War I in the Locarno Treaties of 1925 and the General Act of Arbitration of 1928. The aim of the conciliation was to find a common position between the parties and to propose a non-binding solution. Due to its impartial character, the conciliation was explained as more legal and formal mechanism.

Like inquiry, the conciliation, in fact, was applied in few cases. Conciliation in practice included issues regarding violations of national sovereignty, existence of rights and privileges, compensation for injury to foreign nationals or violation of their vested interests, and interpretation of bilateral treaties (Bernier and Latulippe, p.9). As a mechanism, the conciliation was used in the territorial dispute between Guatemala and Belize, instituted by the Organization of American States (OAS) in 2002. The report of the conciliation 
commission is significant by itself, because the OAS made efforts to encourage the parties to see beyond their dispute in order to reach a solution based on mutual respect and cooperation.

An interesting example is the conciliation between Finland and Norway from 1980 regarding the boundaries of the continental shelf in the Jan Mayen sector (a Norwegian volcanic island situated in the North Arctic Ocean). The report of the conciliation commission included recommendations which were accepted by the parties and led to an agreement in October 1981 (Bernier and Latulippe, p.14).

\section{JUDICIAL MEANS}

The judicial means for dispute settlement is represented by two essential means: arbitration and proceedings in a court of law. Compared to non-binding effect of reports and conclusions typical for diplomatic means, the effect of an arbitral award and court decision is of a binding character.

Inside the division of the judicial means, there is difference between these two procedures. Court of law, its composition, internal structure, procedure, and the law that will be applied in the case are elements that are previously determined by the Statute of the court and they apply to all cases brought before that court. Contrary, in the case of arbitration, these elements are determined by the parties, inside the arbitration agreement called 'compromis'. The intention of both procedures is to solve disputes on the basis of law, but arbitrators can take into consideration all relevant elements and circumstances as well. For that reason, arbitration is often characterized as a quasi-judicial procedure (Simmonds, 1987, pp.149-155).

Nonetheless, there is another difference between the jurisdiction of the court in international and internal law. In internal law, courts of law have compulsory jurisdiction, while arbitration is voluntary and requires the consent of the parties. On the other hand, in international law, the jurisdiction of courts and arbitration depends on the consent of the opposing parties.

\subsection{Arbitration}

Arbitration is recognized as one of the oldest institutions of international law. There is a well-known statement that 'arbitration is only as good as the arbitrators'.

There are no codified rules referred to its functioning, mainly because the parties create the rules by themselves. However, different organizations (such as United Nations) and its bodies (for instance, the General Assembly or some of the specialized agencies of the UN) have formulated model rules that parties can use for settlement of their dispute. The parties of the dispute can incorporate these model rules into the agreement called 'compromis' or may include a reference to any set of model rules.

The 'compromis' itself often includes provisions regarding structure of the tribunal, the process of selection of arbiters and their competencies, procedural issues, the rules that will be applied in the case, and the subject matter.

If a party is not satisfied with the arbitral award it may challenge it on the grounds of: exceeding the powers of the tribunal, corruption on the part of the tribunal or arbiter, severe departure from the procedure or the rules, and the nullity of the compromise or the possibility to take the dispute before arbitration.

Fraud and error are two additional factors that may also weaken the validity of the arbitral awards. For instance, the non-disclosure clause in the agreement can be an example of fraud. Errors can be divided in two main categories: errors in the interpretation or application of law and errors of fact. The latter category is linked to fact based on evidence and if it is detected after the end of the procedure it can be corrected by revision. The other type of errors - errors in the interpretation or application of the law can be taken into account only if they represent 'obvious' or 'essential' errors.

As mentioned above, the parties agree on the rules themselves and include those rules in the 'compromis'. In some cases, the parties formulate the rules by themselves and in other cases, the parties referred to the rules of international law. This is also the case whenever the 'compromis' does not include a set of previously agreed rules. In that situation it can be generally assumed that the rules of international law will be applied.

Other feature of the arbitration is the opportunity given to the parties to choose the composition of the arbitration tribunal and to select the arbitrators. The parties can appoint them by name or they can create a procedure for their appointment. The number of arbitrators must be uneven, in most cases it consist of three members. Each party appoints own arbitrator and both of them agree on the 'neutral' one. If the common agreement cannot be reached between the parties, than a third party, usually the president of the International Court of Justice would be authorized to appoint the 'neutral' arbitrator or the chairman. The member of the arbitral tribunal may not be a national or a habitual residence of any of the parties 
(Lapidoth,pp. 24-26).

A dispute can be submitted to the arbitration with or without the consent of both parties or unilaterally by one of the parties. The parties need to agree on the subject matter of their dispute, and in a case they do not agree on this question, the tribunal will determine it.

At the request of the parties, the arbitral tribunal may suggest 'interim measures' of protection which are not mandatory. The arbitrators and the parties must protect the confidentiality of any confidential information they received in the proceedings. Both parties bear the expenses for the procedure in equal parts.

Although there is no opportunity for a third party to interfere in arbitration, if the tribunal agrees the third party that has a legal interest in the subject matter may interfere in the process.

The process ends with an award which includes the reasons on which it is based. Any of the arbitrators may add individual or dissenting opinion (Lapidoth, p.27). The appellate procedure is allowed only if the parties agreed on it previously. Otherwise there is no possibility to appeal against the arbitral award.

The arbitrators are considered as a type of judges. Parties have the duty to appoint them, but they do not make decisions upon the parties' orders. It is a formal method with a binding effect, and for that reason, as a method of adjudication it is usually explained as one that applies the law. The parties will prefer the arbitration, as a more attractive method, rather than adjudication in a court of law, because of its flexibility, the private proceedings, the opportunity for the parties to formulate the subject matter and the procedure. Over the years a great quantity of arbitrations at international level has been performed and a great amount of international law regarding them (Palmer, 2012, p.43).

\subsection{International Court of Justice}

The International Court of Justice (further in the text: ICJ or the Court) is a descendant of the Permanent Court of Justice that was a judicial organ of the League of Nations. After Second World War and establishing of the United Nations in 1945, this court was replaced by the International Court of Justice. All member states of the UN are automatically parties of the Statute of the ICJ, but its jurisdiction is no mandatory for them. In many cases, the decision about the jurisdiction of the ICJ is up to the Court itself. The ICJ consists of 15 judges, elected for nine years.

The Court adjudicates only disputes between States, because only States may be parties in cases before the ICJ. It represents the apex of the dispute settlement pyramid (Rosenne, 2006).

The Statute of ICJ, as a founding act of the Court, in Article 38 specifies a list of main sources, namely of international law, that can be applied by the Court in its jurisdiction. The main sources are: customs, international conventions, and the general principles of law recognized by the civilized nations. There are two additional sources of law that are not enumerated in the Article 38 of the Statute of ICJ, but may be applied by the court: certain resolutions of international organizations and principles of equity or justice (to decide a case ex aequo et bono ${ }^{10}$ ).

After the written and oral phase of the procedure, the judges decide the case by a majority of the present judges. Although the judgments have to be implemented by the parties, they are not binding as precedents for other cases. There is also a possibility for revision of a judgment if a fact is discovered afterwards and it was not known to the party that requests the revision and to the Court.

The jurisdiction of the ICJ is consensual and the states have no obligation to accept its compulsory jurisdiction. In 1945, when United Nations was founded, Australia and New Zealand insisted on compulsory jurisdiction of the ICJ in respect of all members, but their attempt was unsuccessful due to the opinions of the great powers. The United Kingdom is the only member state of all five permanent members of the Security Council that accepted the compulsory jurisdiction of the Court. Other permanent members of the Security Council have different stories behind their refusal. For instance, the acceptance of the Court's compulsory jurisdiction was terminated by France in the beginning of the Nuclear Tests Case (Australia vs. France and New Zealand vs. France in 1973/1974). The United States of America terminated the acceptance of the jurisdiction as a consequence of the Court decision in the case Nicaragua vs. United States of America from 1986 (the case was about military and paramilitary activities in and against Nicaragua, in particular the laying of mines in ports of Nicaragua). Other two permanent members of the Security Council, China and Russia,

\footnotetext{
${ }^{10}$ The principle 'ex aequo et bono' means in accordance with justice and regardless of the law. So far, there has not been such a case, which proves that states would choose arbitration or some other mechanism for settlement of their dispute if they wished a decision irrespective of the law.
} 
have never accepted the compulsory jurisdiction - either by special agreement ${ }^{11}$ or under the optional clause $^{12}$ (Palmer, 2012, pp. 44-45).

Whenever a State as a party of a dispute addresses to the ICJ it indicates that all other instances or methods are exhausted. Another opinion is that once a dispute comes to the ICJ, there is no longer place for diplomats, but for judges only. Both views do not reflect the reality, because there are cases in which the ICJ is seized without the exhaustion of other peaceful means, in particular the negotiations. There are also cases in which the parties did not make any attempt to solve the dispute by other peaceful means. On the other hand, other peaceful means may be used after the institution of proceedings, considering usage of extra judicial means due to achieving the settlement during the case (Kohen, 2013, p.13).

\section{NEGOTIATIONS OR MEDIATION - WHAT DO PARTIES PREFER?}

The comparison between direct negotiations and mediation reveals not only differences, but common grounds as well. The most usual explanation is that mediation is basically 'assisted negotiation'. Their differences are based on five of their characteristics: flexibility, speed, cost, settlement and enforcement of the agreement, and the autonomy of the parties in the process.

In their mutual comparison, the negotiation is more flexible mechanism than mediation. Although the mediation has a certain amount of flexibility, it is a mechanism where the actions of the parties are undertaken in the presence of a mediator as a third party. The mediator, as a key figure must have influence and control in order to assist the communication between parties.

Negotiation does not require any preparation and is quicker than mediation. On the other hand, mediation is more time consuming and requires prior preparation: the mediator has to be familiar with the subject matter of the dispute and to be available during the process. Mediation requires location and facilities for the separate meetings of mediator with each of the parties.

In this context, the direct negotiations should be cheaper compared to mediation, but only if they are successful and finalized with a settlement. The required venue for the meetings, additional staff, drafting the agreement, facilities and preparation time make mediation more expensive.

The autonomy of the parties and the opportunity to control the process is more prominent in the process of negotiations. In the process of mediation the parties have control, but it is not complete and have no absolute nature.

The last different feature is related to settlement of the dispute and enforcement of the agreement. Settlement of the dispute in mediation is achieved with the assistance of the mediator as a qualified professional who is familiar with the requirements for binding agreement and its enforcement. The negotiations resolve the dispute in accordance with the capability of the parties to reach a satisfactory agreement that correspond to the interests of the parties.

In accordance with this comparison the obvious conclusion is that the opposing parties will prefer negotiations as a first step in any dispute settlement, because of its speed, flexibility and lower costs. If the parties desire inexpensive and speedy resolution of their dispute, then the negotiation is the most ideal mechanism, since it requires no involvement of third party (Sander, 2014, p.9). However, as a method it is not always successful. The communication between the parties can be difficult sometimes, mainly if the parties do not understand their real positions or as a result of existing or past antagonism between them. After the failure of the negotiations, mediation can be used as an effective alternative mechanism. The communication and cooperation between the parties of the dispute can be restored with the assistance of the mediator, as a major figure in the process of mediation, and the formal nature of the mediation.

The mediation is often connected with the United Nations and the attempts to respond effectively to threats to international peace and security. In this manner, the practice identifies four areas of activity: preventive diplomacy, peacekeeping, peacemaking and post-conflict peace-building.

The first one, the preventive diplomacy, by definition, is an action to prevent disputes between the parties, to prevent escalation of existing disputes into conflicts, and if conflict occur - to limit its spread. For the aims of

\footnotetext{
${ }^{11}$ The acceptance of the jurisdiction of the ICJ by special agreement is related to a particular (existing) dispute between the parties.

${ }^{12}$ The jurisdiction of the ICJ may be accepted by an optional clause. The important characteristic is the theory of reciprocity under which it operates. Basically, when the parties of the dispute accept a common commitment, the jurisdiction of the ICJ may be extended only to the extent of that commitment. It is usually determined at the time the ICJ is seized of a case.
} 
this paper, the peacemaking is essential, because it can be related to the mediation itself. Thus, peacemaking covers the action of bringing opposing and hostile parties to agreement, through peaceful means for dispute settlement as foreseen in the Charter of the United Nations (Chapter VI). It includes mediation in order to convince the parties to end hostilities and to negotiate a peaceful settlement. The distinction between preventive diplomacy and peacemaking is in the time frame. Namely, the preventive diplomacy can also include the use of mediation, but it is employed in the phase before the dispute becomes violent. On the other hand, the peacemaking is used to cease the existing conflict and to find a solution that can maintain the peace (Murithi, 2015, p.6).

\section{CONCLUSION}

In the process of dispute settlement, there is a general obligation for direct negotiations initiated upon the request of one of the parties. If negotiations failed and no agreement is reached, the parties may jointly seek some of the others peaceful means for resolving their dispute. Other possible procedures, such as mediation, conciliation or a 'good offices' are optional and require the consent of both parties of the dispute.

The distinction between all diplomatic peaceful means for dispute settlement is not sharply defined and fixed and there are different modes and shades in each of them. It is also possible for the parties to create a new mechanism by combination of several techniques. Hence, there are few characteristics which distinguish them. First of all, the lack of an obligation to choose them, except in case of a prior commitment by the parties; second, the conclusions and reports have non-binding effect on the opposing parties; and finally, there is a possibility to take into consideration all the relevant elements.

On the other hand, the use of some of the judicial means is also optional, but their decisions have binding effect to the parties and they have to be implemented. There are differences in procedures between an arbitral tribunal and the ICJ. One of the main characteristics of the arbitration is its flexibility and adaptability to the wishes of the parties, primarily regarding the rules of the procedure and the selection of the arbitrators.

Compared to the ICJ, its proceedings are undoubtedly more strict and inflexible, the procedure is determined by the Statute of the ICJ and the Rules of procedure, and the Court makes a judgment upon the international law. The parties can influence the procedure only in the part of their possibility to choose adjudication by a chamber and their opportunity to influence on the selection of the judges that will deal with their case.

Although the practice confirms that the diplomatic means for dispute settlement are the most frequently used and the list of cases in front of the ICJ is also extraordinary.

Whenever the parties need to choose the procedure or mechanism for settlement of their dispute there are few questions that need to be taken into consideration. The first one involves the nature of the dispute - is it a legal or a political dispute? Second, is it a disagreement on questions of facts or of law, or maybe, of both?

Third, is it of a technical nature? Fourth, is it an existing dispute or it can still be avoided by preventive measures? Fifth, what are the general relations between the opposing parties? Sixth, does the dispute include vital interests of a State?

As explained in the paper, the disputes in international law can be solved by a broad range of mechanisms of which adjudication is the least popular. In each dispute the opposing parties need to be prepared to make compromise in order to solve their misunderstanding. Often the resolution cannot be obtained because of the political motives and positions of the parties. However, the law and legal principles have always had a significant influence in the dispute settlement. The resolution of a dispute depends not so much on the mechanism, as on the capacity of the parties to choose the right mechanism that correspond to the features of their dispute. On the other hand, there is neither good will nor determination on the side of the state's representatives to accept third-party adjudication. To surrender the dispute to a third party to resolve it, will decrease the power of the domestic decision makers to play an important role in the resolution of that dispute. This attitude is obvious in the resistance to the compulsory jurisdiction of the ICJ and other judicial means. In situations like this one, the political factors are losing control over resolution of the dispute and consequently, it is a threat to their capacity to maintain the power over the circumstances. For these reasons, the essential incentive at the international level should be the effort to intensify the usage of judicial means for dispute settlement, because the arbitral and court procedures cannot be subjects to the weakness created by the strong political influence coming from the political factors. 


\section{REFERENCE LIST}

Bernier, Ivan and Latulippe, Nathalie. The International Convention on the protection and promotion of the diversity of cultural expressions: Conciliation as a dispute resolution method in the cultural sector. Available at: http://www.diversiteculturelle.qc.ca/fileadmin/documents/pdf/document reflexion eng.pdf [accessed 30th November 2016]

Brennan, Lorraine M.(2015). Preparing the client in an international mediation: what to expect from the process. In: Rovine, Arthur W., Contemporary issues in international arbitration and mediation: The Fordham papers. Koninklijke Brill NV, Leiden, The Netherlands.

Charter of the United Nations.(1945). Available at: http://www.un.org/en/sections/un-charter/un-charter-fulltext/ [accessed: $10^{\text {th }}$ December 2016]

French, Duncan, Saul, Mathew and White, Nigel.(2010). (eds.). International law and dispute settlement: New problems and techniques, Hart Publishing, Oxford.

Hague Convention for the Pacific Settlement of International Disputes. (1899). Available at: https://www.loc.gov/law/help/us-treaties/bevans/m-ust000001-0230.pdf [accessed: 8th December 2016]

Hague Convention for the Pacific Settlement of International Disputes. (1907). Available at:

https://cil.nus.edu.sg/rp/il/pdf/1907\%20The\%20Hague\%20Convention\%20for\%20the\%20Pacific\%20Settlem ent\%200f\%20International\%20Disputes-pdf.pdf [accessed: 8th December 2016]

Kohen, Marcelo.(2013). Interaction between diplomatic and judicial means at the initiation of proceedings. In: De Chazournes, Laurence Boisson, Kohen, Marcelo and Vinũales, Jorge E. (eds.). Diplomatic and judicial means of dispute settlement. MartinusNijhoff, Leiden, Boston.

Lapidoth, Ruth. Some reflections on peaceful means for the settlement of inter-state disputes. Georgetown University Law Center. Available at: http://ciwr.ucanr.edu/files/186748.pdf [accessed: 5th December 2016]

Merrills, J.G. (2011). International dispute settlement. $5^{\text {th }}$ ed. Cambridge University Press.

Murithi, Tim. (2015).The failure of the UN Security Council in creating the framework conditions for mediation. Paper presented at the International Mediation Conference, 2-4 June 2015, University of Pretoria, South Africa, Centre for Mediation, Department for Political Sciences.

Murphy, Sean D. (2002). United States practice in International Law. Volume 1: 1999-2001. Cambridge University Press.

Peck, Connie. (1996). The United Nations as a dispute settlement system: improving mechanisms for the prevention and resolution of conflict. Kluwer Law International, The Hague.

Petersman, Ernst-Ulrich. (2004). Justice as Conflict resolution: proliferation, fragmentation and decentralization of dispute settlement in international trade. EUI Working Paper LAW No.2004/10. European University Institute, Florence, Department of Law.

Palmer, Geoffrey. (2012). Perspectives on international dispute settlement from a participant, VUWLR, Vol.43.

Peters, Anne. (2003). International dispute settlement: a network of cooperational duties. EJIL, Vol.14, No.1: 1-34.

Rosenne, Shabtai. (2006). The law and practice of the International Court of Justice 1920-2005. $4^{\text {th }}$ ed. MartinusNijhoft, Leiden.

Sander, Frank E.A. (2014). Alternative dispute resolution in the United States: An overview. In: Betancourt, Julio Cesar, and Crook, Jason A. (eds.) ADR, Arbitration, and Mediation: A collection of essays. CIArb Chartered Institute of Arbitrators. Author House UK.

Simmonds, Kenneth R. (1987). Public International Arbitration - Roundtable, 22 Texas International Law Journal.

Strutt, Keith. (2014). Mediation vs. negotiation. The Driver Trett Digest. Driver Group, London. Available at: https://www.driver-group.com/wp-content/uploads/2015/06/BYTE-9-MEDIATION-VS- 
NEGOTIATION.pdf [accessed: 5th December 2016]

Ury,William, Brett, Jeanne M., Goldberg, Stephen B. (1988). Getting disputes resolved: designing systems to cut the costs of conflict. Jossey-Bass. University of Michigan.

Vienna Convention on the Law of Treaties 1155 UNTS 331. 8ILM 679. (1969). Available at: https://treaties.un.org/doc/Publication/UNTS/Volume\%201155/volume-1155-I-18232-English.pdf [accessed: 10th December 2016]

Vienna Convention on Succession of States in Respect of Treaties 1946 UNTS 3. (1978). Available at:http://legal.un.org/ilc/texts/instruments/english/conventions/3 2 1978.pdf $\quad$ [accessed: 10th December 2016] 